\title{
Bilateral tadpole pupils
}

Figure Bilateral tadpole pupils in patient with congenital erythropoietic protoporphyria
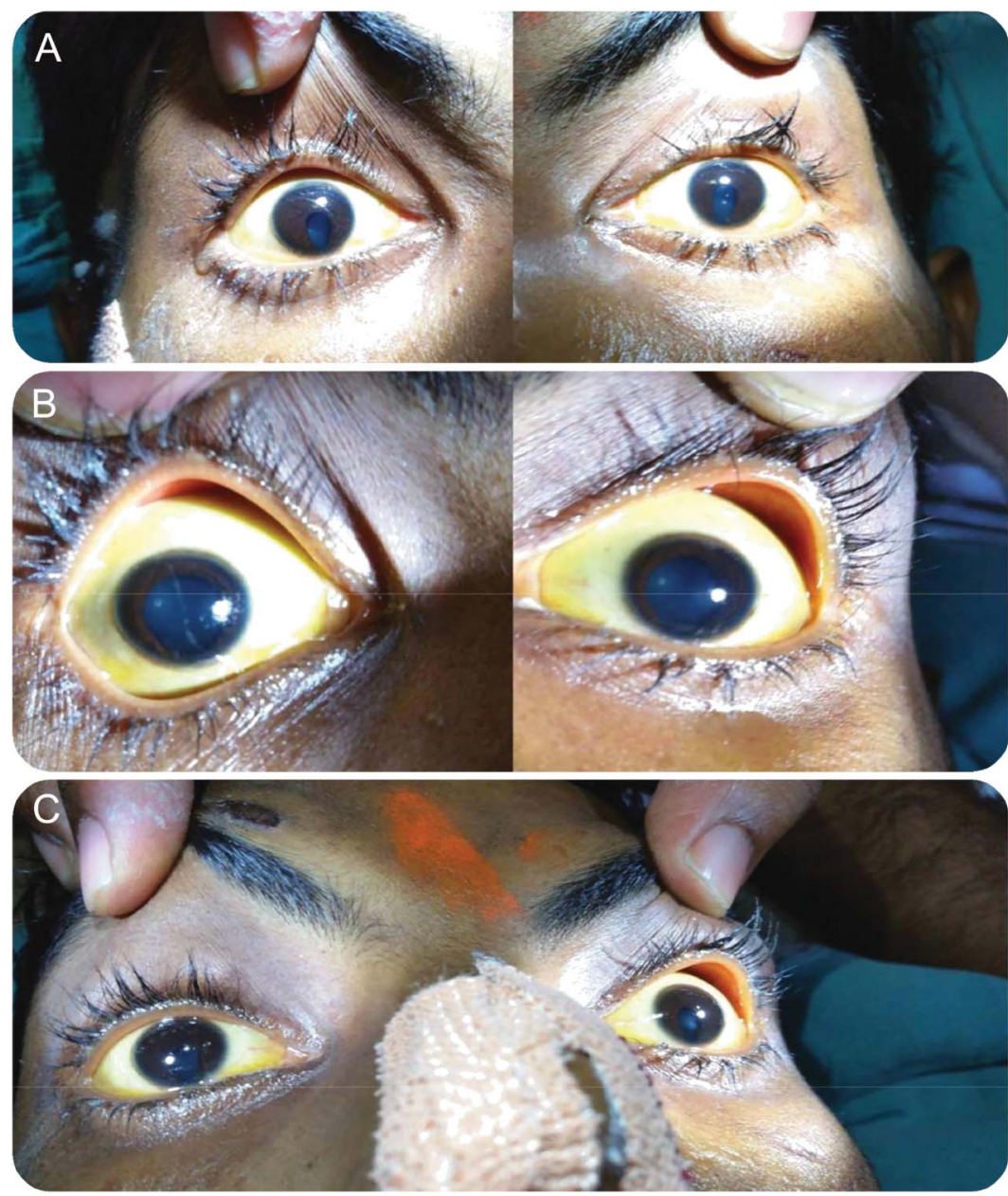

(A) Eye examination at admission showed bilateral nonconstricting tadpole pupils. (B) After mydriatic use, pupils dilate fully but maintain slight tadpole configuration. (C) After mydriatic effect wears off, pupils return to baseline tadpole pupils state.

A 19-year-old man with congenital erythropoietic protoporphyria and without family history or prior migraine attacks had recurrent seizures, which were controlled on propofol. Eye examination performed while awake revealed nonreacting bilateral tadpole pupils (TPs) (figure), without other neurologic deficits. He was hyponatremic $(109 \mathrm{mmol} / \mathrm{L})$, slowly corrected ( $134 \mathrm{mmol} / \mathrm{L}$ in 72 hours) but with episodic bilateral TPs persisting; orbitocranial MRI was normal.

Segmental spasms of iris dilator can cause unilateral TP secondary to Horner syndrome. ${ }^{1}$ Bilateral TPs is rare. In our patient, we postulate autonomic neuropathy ${ }^{2}$ coupled with severe hyponatremia as the etiology. Persistent bilateral TPs warrants investigation to rule out systemic disorders.

Rajan Vijayaraghavan, MD, Cyriac Abby Philips, MD, Shakti Prasad Choudhury, MD

From the Unit of the Critically Ill Cirrhotic, Institute of Liver and Biliary Sciences, New Delhi, India. 
Author contributions: Dr. Rajan Vijayaraghavan: concept, first draft. Dr. Cyriac Abby Philips: concept and design, final draft. Dr. Shakti Prasad Choudhury: data acquisition, figures.

Study funding: No targeted funding reported.

Disclosure: The authors report no disclosures relevant to the manuscript. Go to Neurology.org for full disclosures.

Correspondence to Dr. Philips: abbyphilips@gmail.com

1. Kawasaki A, Mayer C. Tadpole pupil. Neurology 2012;79:949.

2. Bremner FD, Smith SE. Pupil abnormalities in selected autonomic neuropathies. J Neuroophthalmol 2006;26:209-219.

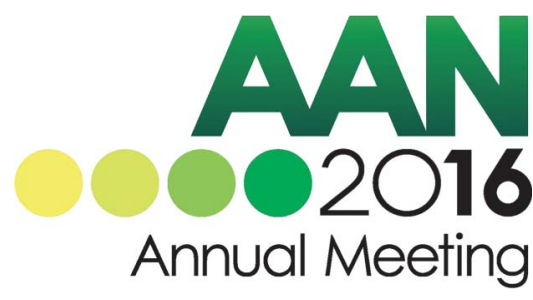

\section{Register Today for the 2016 AAN Annual Meeting}

Register today for the innovative new AAN Annual Meeting, set to take place Friday, April 15, through Thursday, April 21, 2016, at the Vancouver Convention Centre in Vancouver, BC, Canada. The money-saving early registration deadline is March 24, 2016. Visit AAN.com/view/AM16 to learn more and register today!

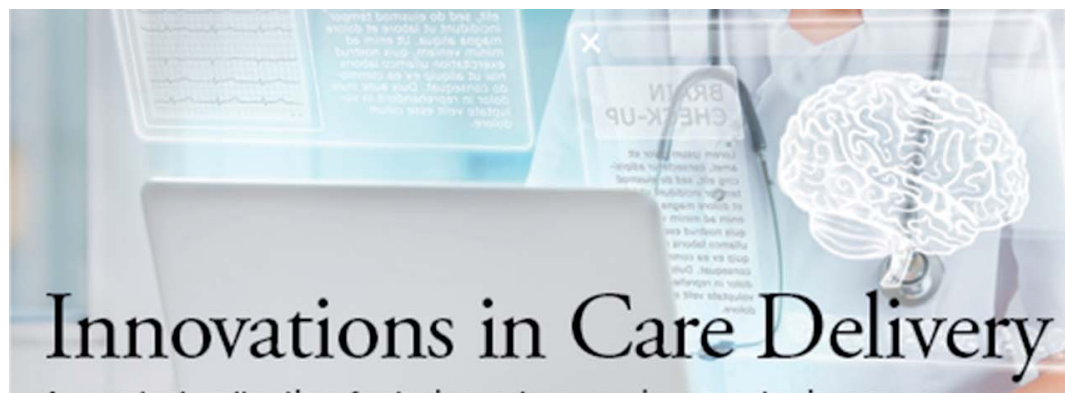

A curated collection featuring advances in neurologic care

\section{NEW! \\ Innovations in Care Delivery - A curated collection featuring advances in neurologic care}

This Neurology ${ }^{\circledR}$ special interest Web site provides a forum to explore new care models from multiple disciplines, access to sources on health care innovation, and expert opinions on current research from Neurology journals. Curated by E. Ray Dorsey, MD, MBA.

Stay ahead of the curve at Neurology.org/innovations. 


\title{
Neurology
}

\author{
Bilateral tadpole pupils \\ Rajan Vijayaraghavan, Cyriac Abby Philips and Shakti Prasad Choudhury \\ Neurology 2016;86;1074-1075 \\ DOI 10.1212/WNL.0000000000002470
}

This information is current as of March 14, 2016

\section{Updated Information \&} Services

References

Permissions \& Licensing

Reprints including high resolution figures, can be found at: http://n.neurology.org/content/86/11/1074.full

This article cites 2 articles, 1 of which you can access for free at: http://n.neurology.org/content/86/11/1074.full\#ref-list-1

Information about reproducing this article in parts (figures,tables) or in its entirety can be found online at:

http://www.neurology.org/about/about_the_journal\#permissions

Information about ordering reprints can be found online:

http://n.neurology.org/subscribers/advertise

Neurology ${ }^{\circledR}$ is the official journal of the American Academy of Neurology. Published continuously since 1951, it is now a weekly with 48 issues per year. Copyright (O 2016 American Academy of Neurology. All rights reserved. Print ISSN: 0028-3878. Online ISSN: 1526-632X.

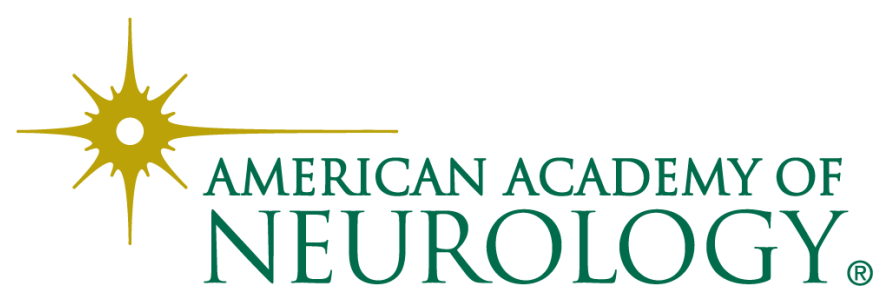

